Goldschmidt, V. M. (1954). Geochemistry. Oxford: Clarendon Press.

Mitchell, R. L. (1947). Proc. int. Congr. Chem. xi. London, 3, I 57.

Mitchell, R. L. (1948). Research, I, I 59.

Mitchell, R. I. (1954). Proc. int. Peat Symp., Dublin, Section B3.

Mitchell, R. L. (1955). In Chemistry of the Soil (Monogr. Ser. Amer. chem. Soc. no. 126), p. 253. [F. E. Bear, editor.] New York: Reinhold Publishing Corp.

Mitchell, R. L., Reith, J. W. S. \& Johnston, I. M. (1957). F. Sci. Fd Agric. 8, S5I.

Nockolds, S. R. \& Mitchell, R. L. (I948). Trans. roy. Soc. Edinb. 61, 533.

Swaine, D. J. \& Mitchell, R. L. (1960). F. Soil Sci. (In the Press.)

Vinogradov, A. P. (1959). The Geochemistry of Rare and Dispersed Chemical Elements in Soils. New York: Consultants Bureau.

Wager, L. R. \& Mitchell, R. L. (195 I). Geochim. et cosmoch. Acta, r, 129.

\title{
Biochemical function of some of the minor elements
}

\author{
By E. C. Owen, Hannah Dairy Research Institute, Kirkhill, Ayr
}

Since copper, molybdenum, sulphur and selenium are being discussed by others the present paper deals with cobalt, zinc, cadmium, manganese and vanadium.

\section{Cobalt}

Vitamin $B_{12}$ (Smith, I957) is needed by non-ruminants to prevent anaemia and ensure optimal growth on food of vegetable origin, and Co is needed by ruminants to enable their symbiotic bacteria to make vitamin $B_{12}$. It is possible also that all these species need $\mathrm{Co}$ in forms other than vitamin $\mathrm{B}_{12}$ since cobaltous ions can activate a number of enzymes (Gajdos, I959; Seekles, I948a-c). Absence of sufficient vitamin $B_{12}$ from human diet or incapacity to absorb it adequately from the food causes pernicious anaemia (PA) in man. PA when fully developed is characterized by a reduced number of circulating red blood cells that have a higher mean diameter and greater range in size than normal. There are also: ( $\mathrm{I}$ ) compensatory hypertrophy of the blood-forming tissues in the marrow of the long bones, (2) a changed histological picture of the bone marrow (obtained by sternal puncture) and (3) an atrophy of the stomach wall accompanied by achlorhydria and failure to produce Castle's intrinsic factor (IF). There may also be neuropathological symptoms aggravated or even precipitated by folic-acid therapy. The marrow cells need both folic acid and vitamin $B_{12}$ for normal erythropoiesis, and folic acid probably prevents the marrow from getting its full share of a poor supply of vitamin $B_{12}$ (Wintrobe, I956). The megaloblastic anaemia of vitamin $B_{12}$ deficiency can be due to abnormalities of the stomach, to a dietary deficiency or to inhibition of normal vitamin $\mathrm{B}_{12}$ absorption, by bacteria in the small intestine, as in sprue (Halsted, Carrol \& Rubert, I959).

Heathcote \& Mooney (I958) think that IF is not really intrinsic but is a peptide resulting from the digestion of vitamin $B_{12}$-protein complexes in the food. This heterodox view would make the absence of IF merely an effect of achlorhydria. Concentrates of the stomach mucosa of the pig and rat containing IF activity are effective in man, but their chemical nature (Keuning, Arends, Mandema \& Nieweg, I959) and mode of operation (Wolff \& Vuillemin-Weis, I958; Taylor, Mallett, Witts \& Taylor, 1958; Grasbeck \& Nyberg, 1958; Herbert, 1959) are still in dispute. 
Vitamin $B_{12}$ deficiency is a special hazard to strict vegetarians (Wokes, 1958 ) in whom a low intake may be aggravated by a high intake of folic acid from green foods. A diagnosis of $\mathrm{PA}$ is confirmed if oral vitamin $\mathrm{B}_{12}$ fails noticeably to increase the excretion of vitamin $B_{12}$ in the urine (Gaffney, Watkin \& Chow, 1959) and injected vitamin $B_{12}$ causes a transient increase in circulating reticulocytes. The life of the red cells may be reduced. In PA, vitamin $B_{12}$ excretion in the urine can be increased by giving the vitamin $B_{12}$ by mouth along with human or pig or rat IF or perhaps D-sorbitol (Greenberg, Herndon, Rice, Parmelee, Gulesich \& Van Loon, 1957) although the effect of sorbitol is disputed by Chalmers \& Skinton (1959). Gastrectomy in man or the rat inhibits the output of vitamin $B_{12}$ in urine, and vitamin $B_{12}$, either injected or given orally together with $I F$, will remove this inhibition. Nieweg, Shen \& Castle (1957) showed that the absorption in vitro of vitamin $\mathrm{B}_{12}$ by the small intestine of the rat was facilitated by rat, but not by human or pig, IF. In some PA patients pig IF becomes inactive after a time and this effect has been attributed to an immune reaction (Taylor \& Morton, I959; Schwartz, Lous \& Meulengracht, 1959). A taurinuria (Todd, I959) is found in PA possibly from an excessive katabolism of methionine to provide one-carbon methyl precursors (Arnstein, 1960), since vitamin $B_{12}$ is believed to be required for the formation of uracil (and so of ribonucleic acid) and folic acid for the methylation of uracil to thymine and so for the formation of deoxyribonucleic acid. Both uracil and thymine are haematopoietic in PA. In man, absorption of vitamin $B_{12}$ from the gut occurs in the ileum (Booth \& Mollin, I959). It is believed, in most species, to be negligible further along the gut, so that faeces of animals and even faeces of PA patients may be rich in vitamin $B_{12}$. The rabbit is exceptional as it eats its night faeces. Rats also survive on vitamin $\mathrm{B}_{12}$-deficient diets unless prevented from eating their faeces. Wokes ( $\left.195^{8}\right)$ has suggested that intestinal synthesis allows strict vegetarians to live apparently in robust health. Perhaps vitamin $B_{12}$ is absorbed in some people from the large bowel or the rectum as are thiamime and nicotinic acid (Najjar \& Holt, 1943).

The distribution of vitamin $B_{12}$ in nature, in contrast to that of other vitamins, which are found in fungi, green plants and bacteria, is consistent with a general belief that only bacteria, e.g. Streptomyces griseus, Escherichia coli, and possibly blue-green algae (Holm-Hansen, Gerloff \& Skoog, 1954) make it from Co salts (see Owen, I959a,b,c). Exacting bacteria such as Lactobacillus lactis Dorner, Lactobacillus leichmannii, E. coli (mutant) and the phytoflagellate Euglena gracilis, or Ochromonas malhamensis, which botanists classify as a brown alga and zoologists as a protozoan, can be used for assaying vitamin $\mathrm{B}_{12}$ and other cobalamins. Ochromonas has become the organism of choice because it responds specifically to vitamin $B_{12}$. Where bacteria abound-in faeces and sewage, in the rumen, caecum or colon, and in the sapropelic muds of lake floors (Kuceva \& Bukin, 1957)-cobalamins, including vitamin $B_{12}$, are also abundant. This is why ruminants do not require vitamin $B_{12}$ and why ruminant meat and milk are good sources of vitamin $B_{12}$ in human foods. It is obtained also from fish and seaweed. Seaweed gains vitamin $B_{12}$ from its epiphytic bacteria and most marine organisms harbour symbiotic bacteria (Buchner, 
1953) which no doubt account for their vitamin $B_{12}$ content. Parts of certain leguminous plants, e.g. lucerne leaves and groundnuts, have been reported to contain traces of vitamin $\mathrm{B}_{12}$ and Reisenauer (1960) has shown that lucerne fixes more nitrogen when Co is added to a deficient culture solution. Rhizobium radicicola is known to be able to synthesize not only vitamin $B_{12}$ in vitro but also haemoglobin in the root-nodules. Allen (1956) has found that protoporphyrin accumulates in the blood of Co-deficient sheep and that iron reserves of such sheep are adequate. It seems therefore as though an important lesion of pining sheep, of PA patients and even possibly of Co-deficient legumes may be the absence of vitamin $B_{12}$ from some as yet uncharacterized enzyme system enabling ferrous iron to combine with protoporphyrin to form haem and hence haemoglobin. The large tapeworm, Diphyllobothrium latum, which by attaching itself to the jejunum of man and absorbing vitamin $\mathrm{B}_{12}$ at a faster rate than the host causes PA to develop, has freshwater fish as intermediate hosts. This anaemia was first reported from Finland but is also found in Chile and round the Great Lakes of North America. The signs disappear if the worm is expelled and can be ameliorated if a powder made of the dried worm is eaten.

Wagle, Mehta \& Johnson (1958a,b) reported that vitamin $\mathrm{B}_{12}$ was specifically required by the protein-synthesizing system in rat liver described by Hoagland, Keller \& Zamecnik (1956) but this statement has been disputed by Fraser \& Holdsworth (1959) and Arnstein \& Simkin (1959).

Photolysis of vitamin $B_{12}$ in vitro produces hydroxocobalamin and cyanide, and Mushett, Kelley, Boxer \& Rickards (1952) have shown that hydroxocobalamin is an efficient antidote to cyanide, that traces of cyanide are a normal constituent of human $(2-3 \mu \mathrm{g} / \mathrm{h})$ and rat $(0 \cdot \mathrm{I}-0.2 \mu \mathrm{g} / \mathrm{h})$ breath and that its evolution in the breath parallels the metabolic rate which is regulated by thyroxine. Moreover, vitamin $B_{12}$ makes rats more resistant to thyroxine (Kasbekar, Lavate, Rege \& Sreenivasan, 1959) and thyroxine increases the rat's need for vitamin $\mathrm{B}_{12}$. There is a system in erythrocytes which liberates $\mathrm{CN}^{\prime}$ from $\mathrm{CNS}^{\prime}$, and Lang's (1933a,b) rhodanese enzyme in the liver converts $\mathrm{CN}^{\prime}$ into $\mathrm{CNS}^{\prime}$. The liver is the site of $\mathrm{CN}^{\prime}$ detoxication in the ruminant (Blakeley \& Coop, r949). $\mathrm{CN}^{\prime}$ in chronic doses of $3 \mathrm{mg} \mathrm{KCN} / \mathrm{kg}$ daily causes a progressive demyelinization without necrosis of the cerebral white matter in monkeys (Hurst, r942) possibly through interference with the copper-containing cytochrome oxidase which is deficient in brains of swayback lambs. Cretinism, myxoedema, pellagra (in the last of which there is both a thiocyanuria and a sulphur deficiency) and PA show that thyroxine, sulphur, nicotinic acid and vitamin $B_{12}$ are all with copper in some way responsible for the integrity of the nervous system. Possibly all these substances are required to prevent cyanide from exceeding a necessary but very low level in the body and they are all at various points involved in the enzyme system shown in Fig. I. The figure depicts the hypothesis that the goitrogen, CNS', is possibly one of the body's means of limiting thyroxine output, since the faster thyroxine causes katabolism of labile liver cytoplasm the greater the production of CNS' from endogenous cyanide. CNS' is known to reduce the uptake of iodide by the thyroids if sufficient is present (see Owen, I959c). It should be noted 


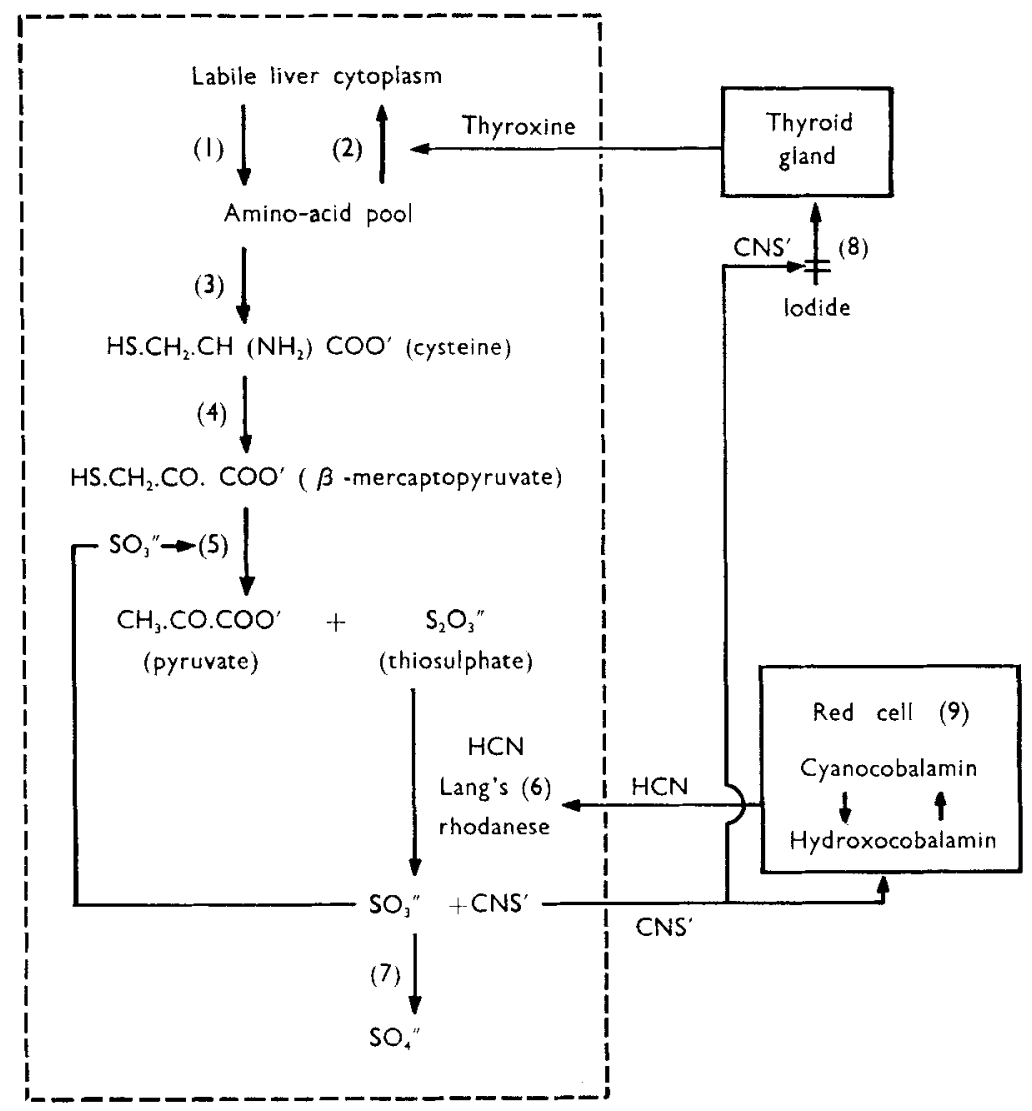

Fig. I. Diagrammatic representation of the hypothesis that vitamin $\mathbf{B}_{12}$ and normal katabolites of methionine and cystine are the vehicles that may reduce the uptake of iodide by the thyroid gland.

Figures in parentheses on the diagram refer to: (I) amino- and carboxy-peptidases of which the former is activated by zinc or by several other bivalent metal ions and the latter has $\mathrm{Zn}$ as an integral part of its molecule (Vallee, I959); (2) protein-synthesizing enzyme of Hoagland $e t$ al. (1956) believed by Wagle et al. $(1958 a, b)$ but not by Fraser \& Holdsworth (1959) or Arnstein \& Simkin (1959) to need vitamin $B_{12}$ for its action; (3) amino-acid pool in equilibrium with amino acids from hepatic blood and therefore from diet; (4) oxidative deaminase; (5) B-mercaptopyruvate sulphotransferase (Kun \& Fanshier, 1959) which contains copper; (6) rhodanese (Lang, 1933a,b); (7) xanthine oxidase which contains iron and molybdenum and has sulphite-oxidase activity (Fridovich \& Handler, I958a,b); $(8)$ iodide uptake of the thyroid gland reduced by $\mathrm{CNS}^{\prime}$; (9) enzyme in erythrocytes which produces $\mathrm{CN}^{\prime}$ from $\mathrm{CNS}^{\prime}$ (Pines \& Crymble, 1952).

that normally the concentration of CNS' in human plasma is about $\mathrm{I}-2 \mu \mathrm{g} / \mathrm{ml}$ and that concentrations of $50 \mu \mathrm{g} / \mathrm{ml}$ have caused hyperplasia of the thyroid and signs of deficiency. Vitamin $\mathrm{B}_{12}$ in the liver could act as a harmless reservoir of endogenous cyanide (Wokes \& Piccard, I955).

\section{Zinc}

The metabolic role of $\mathrm{Zn}$ has been reviewed by Underwood (1956) and Vallee (1959). $\mathrm{Zn}$ is a constituent of the carbonic anhydrase of bovine erythrocytes (Keilin 
\& Mann, 1940), and also of carbonic anhydrases of other organs of the body and of plant tissues. Carbonic anhydrase is inhibited by sulphonamide but not, according to Vallee ( 1959), through the $\mathrm{Zn}$ of its molecule. $\mathrm{Zn}$ is an essential trace element for all forms of life so far investigated but in excess is toxic even when free from cadmium and arsenic. Studies of parakeratosis in the pig show that on dry diets rich in $\mathrm{Ca}$ the pig has an unexpectedly large requirement for $\mathrm{Zn}$, and this disease, which is characterized by dermatitis, diarrhoea, vomiting and lack of appetite, is cured by $\mathrm{Zn}$. To a ration containing $2 \cdot 2 \% \mathrm{Ca}$, Wilkie \& Bussell (I958) added 230 p.p.m. Zn to prevent the disorder and this supplement improved growth even in the apparently unaffected animals. When ${ }^{65} \mathrm{Zn}$ was injected intravenously, faecal metabolic $\mathrm{Zn}$ and $\mathrm{Zn}$ in the liver had a significantly greater specific activity in pigs on a high-Ca diet than in those on a normal diet so that the high Ca was causing a more rapid turnover of $\mathrm{Zn}$ (Newland, Ullrey, Hoefer \& Luecke, I958). Hallgren \& Swahn (1957) state that citric or acetic acid can prevent parakeratosis due to excess $\mathrm{Ca}$ as effectively as $Z n$ added to dry feeds, though it does not seem clear why wet foods should prevent the disease that would occur with the same rations given dry. Injected $\mathrm{Zn}$ can improve weight gains of pigs on parakeratosis diets (Lewis, Hoekstra, Grummer \& Phillips, I956). Luecke, Hoefer, Brammel \& Thorp (1956) think that the increasing incidence of parakeratosis is due to the exclusions from the pigs' diets of foods of animal origin such as meat-and-bone scraps. These contain significant amounts of $\mathrm{Zn}$. Possibly a decreased use of galvanized iron may play a part. Stevenson \& Earle (1956) found that alkaline-phosphatase activity in the blood was more variable in pigs with parakeratosis than in controls. This finding is of interest in view of Vallee's ( 1959 ) statement that $\mathrm{Zn}$ is a constituent of alkaline phosphatase of pig kidney. Perpere \& Placidi ( 1956) eventually cured a natural outbreak of parakeratosis with $\mathrm{Zn}$ alone but in prior experiments found aggravation by $\mathrm{Ca}$. Some amelioration of the dermatitis was produced by thiosulphate given by mouth or by injection. $\mathrm{Zn}$ is widely distributed through the tissues of the animal body (Underwood, 1956). The seminal fluid and the prostate gland contain it, and in rats $\mathrm{Zn}$ deficiency produces testicular atrophy. There are significant amounts in the liver and in bone. Much has been written about the relation between $\mathrm{Zn}$ and insulin which, crystallized from pancreas, contains $\mathrm{Zn}$. Over four-fifths of diabetics need dietary correction only. The other fifth have to have medication. Protamine-zinc-insulin is usually injected. According to Vallee (1959) there is as yet no definite evidence that $Z_{n}$ has any specific function in either the production or action of insulin. Nevertheless diabetes in animals has been produced by injections of dithizone, and alloxan, which also produces diabetes, has been shown to interfere with $\mathrm{Zn}$ metabolism. Histological methods are of little use in attempts to connect $Z \mathbf{n}$ with insulin since both the $\beta$-cells which produce the insulin and the $\alpha$-cells of the pancreas which produce glucagon are rich in $\mathrm{Zn}$. In addition the exocrine cells producing pancreatic juice, are also rich in $\mathrm{Zn}$ which is present in carboxypeptidases and activates aminopeptidases (Vallee, I959; Folk \& Gladner, I960; Vallee, Rupley, Coombes \& Neurath, I960). Vallee includes alcohol dehydrogenase of yeast and of equine liver, glutamic dehydrogenase of bovine liver and lactic dehydrogenase of rabbit skeletal muscle in a list 
of enzymes known to contain $\mathrm{Zn}$. It appears therefore that the rate of turnover of $\mathrm{Zn}$ may be high in such active organs as the liver where protein synthesis and hydrolysis are rapid, in the pancreas where protein synthesis is rapid and in the intestinal mucosa where both metabolic activity and rate of replacement of the tissue are very high. Protein synthesis is also rapid in the skin which like the intestinal mucosa is continually being rubbed off. High concentrations of $\mathrm{Zn}$ may indicate merely a high rate of metabolic activity involving a high rate of protein synthesis such as occurs also in the male genital tract. Cadmium injections destroy the testicular tissue of rats and mice (Parizek, I957) but simultaneous administration of $\mathrm{Zn}$ prevents this effect of $\mathrm{Cd}$. High concentrations of $\mathrm{Zn}$ are not found in any of the female genital organs. The importance of some of the enzymes mentioned earlier is obvious but glutamic dehydrogenase deserves special mention for it can catalyse the reversible oxidative deamination of glutamic acid (Vallee, 1959). Vallee lists a number of peptidases with carnosinase, lecithinase, enolase, two aldolases and oxaloacetic decarboxylase as being activated by $\mathrm{Zn}$ or a variety of other divalent metallic ions. Other hormones than insulin have been reported to have their physiological effects magnified by the addition of $\mathrm{Zn}$ and it has been suggested that whale corticotrophin contains $\mathrm{Zn}$. $\mathrm{Zn}$ is reported to increase the activity of the gonadotrophins and it is routinely used in assays of corticotrophin.

Oysters can contain up to $0.3 \% \mathrm{Zn}$ according to Chipman, Rice \& Price (I958) who state that oysters can concentrate $\mathrm{Zn}$ from sea water up to I000 times. Murthy, Goldin \& Campbell (1 959) studied the concentrations of ${ }^{65} \mathrm{Zn}$ in foods and found the greatest concentration in oysters from Chesapeake Bay. They presumed that it came from fall-out. The turnover of ${ }^{65} \mathrm{Zn}$ in marine fish was higher in blood, kidney and liver than in bone, muscle and integument. Obviously fish do not lose their integuments as do land animals or crustacea (Chipman et al. 1958).

Berfenstam (1952) found three times as much $\mathrm{Zn}$ in the blood plasma of ten human foetuses as in average maternal plasma and much more $\mathrm{Zn}$ in both human and cow's colostrum than in milk. Indeed, Nishimura ( 1953 ) produced dermatitis in mice by substituting foster mothers' milk for their own mothers' colostrum for $3 \frac{1}{2}-5 \frac{1}{2}$ days post partum. $\mathrm{Zn}$ added to the foster milk acted preventively.

Vallee ( 1959 ) lists the $\mathrm{Zn}$ content in six different tissues of nineteen different species of animals. There is a notably higher concentration of $\mathrm{Zn}$ in both the choroid and the iris compared with other tissues of the eye in all species. This may be due to the association of $\mathrm{Zn}$ with melanin as pointed out by Bowness $\&$ Morton (1953) and Underwood ( $195^{6}$ ), but the concentrations of $\mathrm{Zn}$ are enormous in the choroid in predators, e.g. trout, perch, frog, fox and marten, and in the isolated tapetum lucidum of the dog, fox, cat, badger and seal; in the last $14.6 \% \mathrm{Zn}$ may be present in the dried material (Vallee, 1959). It is suggested that this may be an adaptation to allow hunting species to see their prey in conditions of failing light. By contrast, the sperm whale has about the same concentration of $\mathrm{Zn}$ in the choroid as in the lens which has the lowest concentration of all the tissues in all the species studied. Vallee also reports that a smaller quantity of dithizone than is needed to induce diabetes 
will cause blindness in dogs within $24 \mathrm{~h}$ through detachment of the retina, presumably because dithizone will shift $\mathrm{Zn}$ into the fat at physiological $\mathrm{pH}$ (Sandell, 1944). A $\mathrm{Zn}$-cysteine monohydrate complex has been isolated from the tapetum lucidum cellulosum of the fox and the seal. Vallee remarks that in the retina vitamin A alcohol and its aldehyde (retinene) are interconvertible by horse-liver alcohol dehydrogenase, a $\mathrm{Zn}$-containing enzyme, and that $\mathrm{Zn}$ is present as a constituent of retinene reductase which may be alcohol dehydrogenase under another name. Retinene (Wald, I935; Bliss, I95 I Ball, Goodwin \& Morton, 1948) is required for the regeneration of visual purple and the dependence of its production on the presence of $\mathrm{Zn}$ may account for the vitamin A-resistant night-blindness which is apt to occur in cases of post-alcoholic cirrhosis of the liver in which low values for hepatic $Z n$ are found (Vallee, I959).

\section{Vanadium}

The tunicates (sea-squirts) contain up to $0.2 \% \mathrm{~V}$ in dry matter and other marine species, e.g. molluscs and bryozoa, may have similar concentrations. In some tunicates are free cells so rich in $\mathrm{V}$ as to be called 'vanadocytes'. In an informative review on $\mathrm{V}$, Nason ( 1958 ) discusses its biochemistry and that of vanadocytes which are possibly symbiotic algae. $\mathrm{V}$ has been reported to inhibit hypercholesterolaemia in rabbits and perhaps in man (Anonymous, I959).

\section{Manganese}

$\mathrm{Mn}$, even when injected, is eliminated in the faeces probably in the bile. $\mathrm{Mn}$ is fairly evenly distributed throughout the body but is especially concentrated in the skeleton, pituitary, liver and pancreas (in that order). The highest concentration has been found in the ox retina (Fore \& Morton, 1952). Arginase (Cotzias, 1958) of which $\mathrm{Mn}$ is a specific activator (Folley \& Greenbaum, 1948) is not needed in the liver of birds because they are uricotelic. Nevertheless, livers of birds do concentrate Mn. Deficiency of $\mathrm{Mn}$ in the diet causes deformities in the bones of dogs, rabbits and poultry. It also causes lameness in pigs. Excess dietary $\mathrm{Ca}$ and $\mathrm{P}$ aggravate $\mathrm{Mn}$ deficiency perhaps by stimulating faecal loss of $\mathrm{Mn}$. The chief sources of dietary $\mathrm{Mn}$ are green foods; tea is particularly rich in $\mathrm{Mn}$ which goes into solution on infusion (Cotzias, 1958). In green foods $\mathrm{Mn}$ may be part of the nitrate-reductase system of enzymes (Nicholas, 1957). Meat is deficient in both $\mathrm{Ca}$ and $\mathrm{Mn}$. Milk is poorer than colostrum in $\mathrm{Zn}, \mathrm{Mn}, \mathrm{Cu}$ and $\mathrm{Fe}$. In the mollusc Pinna squamosa is a pigment, pinnaglobin, which contains Mn. Mn occurs in hen's eggs but deficient diets can cause eggs to contain too little $\mathrm{Mn}$ for hatching unless $\mathrm{Mn}$ is injected into them. Mn deficiency in the fowl causes perosis in adults and chondrodystrophy in the newly hatched. Tissues of Mn-deficient animals are often seriously depleted of alkaline phosphatase, an enzyme activated in both birds and mammals by Mn and of which the substrate is activated by magnesium. Deficiency of Mn may be accompanied by ataxia in rats (Hurley, Everson \& Geiger, 1958) and a similar condition develops in chronic manganosis in pyrolusite miners. There are differences of opinion as to whether or not excess of Mn can precipitate lactation tetany in cattle though experiments have shown that excessive Mn intakes (Fain, Dennis \& Harbaugh, 
1952) may induce hypomagnesaemia. A peculiarity of the livers of Mn-deficient rats is their ability to exhibit normal titres of arginase when $\mathrm{Mn}$ is added to them in vitro. Birds (Underwood, I956) seem to have a greater Mn requirement than mammals, possibly correlated with their rapid mobilization of $\mathrm{Ca}$ and $\mathrm{P}$ when laying eggs, as experiments of Bolton (1955) would seem to suggest. There is an optimum ratio of $\mathrm{Mn}$ to $\mathrm{Fe}$ and of thiamine to $\mathrm{Mn}$ in the diet for normal blood formation (Cotzias, 1958). Mn deficiency can cause reproductive failure in both cows (Underwood, I956; Cotzias, I958) and pigs (Plumlee, Thrasher, Beeson, Andrews \& Parker, I956). Mn can activate a number of animal enzymes (Vallee, I959; Seekles, r948a-c). Wacker \& Vallee (I959) found significant traces of $\mathrm{Mn}$, together with $\mathrm{Cr}, \mathrm{Zn}, \mathrm{Cu}, \mathrm{Sr}$, $\mathrm{Ba}, \mathrm{Ca}, \mathrm{Mg}$ and $\mathrm{Al}$, in ribonucleic acids of tissues of animals and of Euglena gracilis. In the latter $\mathrm{Ni}$ was also found.

\section{REFERENCES}

Anonymous. (1959). Nutr. Rev. 17, 23 I

Allen, S. H. (1956). Biochem. $7.63,461$.

Arnstein, H. R. V. (1960). Biochem. F. 74, 616.

Arnstein, H. R. V. \& Simkin, J. L. (1959). Nature, Lond., 183, 523.

Ball, S., Goodwin, T. W. \& Morton, R. A. (r948). Biochem. F. 42, 5 I6.

Berfenstam, R. (1952). Acta paediat. 4I, 389 .

Blakeley, R. L. \& Coop, I. E. (1949). N.Z. F. Sci. Tech. A, 3т, I.

Bliss, A. F. (1951). Arch. Biochem. 31, I97.

Bolton, W. (1955). Brit. F. Nutr. 9, 170.

Booth, C. C. \& Mollin, D. L. (1959). Lancet, i, 18.

Bowness, J. M. \& Morton, R. A. (1953). Biachem. F. 51, 530.

Buchner, P. (1953). Endosymbiose der Tiere mit pflanzlichen Mikroörganismen. Basel: Birkhaüser.

Chalmers, J. N. M. \& Skinton, N. K. (1959), Nature, Lond., 183, 20.

Chipman, W. A., Rice, T. R. \& Price, T. J. (1958). Fish. Bull., U.S., 58, 279.

Cotzias, G. C. (1958). Physiol. Rev. 38, 503.

Fain, P., Dennis, J. \& Harbaugh, F. G. (1952). Amer. F. vet. Res. 13, 348.

Folk, F. E. \& Gladner, J. A. (1960). F. biol. Chem. 235, 60.

Folley, S. J. \& Greenbaum, A. L. (1948). Biochem. $\mathscr{F} .43,537$.

Fore, H. \& Morton, R. A. (1952). Biochem, F. 51, 600 .

Fraser, M. J. \& Holdsworth, E. S. (1959). Nature, Lond., 183, 519.

Fridovich, I. \& Handler, P. (1958a). F. biol. Chem. 233, I578.

Fridovich, I. \& Handler, P. (1958b). F. biol. Chem. 233, I 58 I.

Gaffney, G. W., Watkin, D. M. \& Chow, B. F. (1959). F. Lab. clin. Med. 53, 525.

Gajdos, A. (1959). Rev. Path. gén. 59, 201.

Grasbeck, R. \& Nyberg, W. (1958). Scand. F. clin. Lab. Invest. 10, 448.

Greenberg, S. M., Herndon, J. F., Rice, E. G., Parmelee, E. 'T., Gulesich, J. J. \& Van Loon, E. J. (1957). Nature, Lond., r80, 1401 .

Hallgren, W. \& Swahn, O. (1957). Nord. VetMed. 9, 489.

Halsted, J. A., Carrol, J. \& Rubert, S. (r959). New Engl. F. Med. 260, 575.

Heathcote, J. G. \& Mooney, F. S. (I958). Lancet, i, 982.

Herbert, V. (1959). Amer. F. clin. Nutr. 7, 433.

Hoagland, M. B., Keller, E. B. \& Zamecnik, P. C. (1956). F. biol. Chem. 218, 345.

Holm-Hansen, O., Gerloff, G. C. \& Skoog, F. (1954). Physiol. Plant. 7, 665.

Hurley, L. S., Everson, G. J. \& Geiger, J. F. (1958). F. Nutr. 66, 309.

Hurst, E. W. (1942). Aust. F. exp. Biol. med. Sci. 20, 297.

Kasbekar, D. K., Lavate, W. V., Rege, D. V. \& Sreenivasan, A. (1959). Biochem. F. 72, 374.

Keilin, D. \& Mann, T. (1940). Biochem. F. 34, $1 \times 63$.

Keuning, F. J., Arends, A., Mandema, E. \& Nieweg, H. O. (1959). F. Lab. clin. Med. 53, 127.

Kuceva, L. S. \& Bukin, V. N. (1957). Dokl. Akad. Nauk. SSSR, 115, 765.

Kun, E. \& Fanshier, D. W. (1959). Biochim. biophys. Acta, 33, 26.

Lang, K. (r933a). Biochem. Z. 259, 243.

Lang, K. (1933b). Biochem. Z. 263, 262.

Lewis, P. K., Hoekstra, W. G., Grummer, R. H. \& Phillips, P. H. (1956). J. Anim. Sci. 15, 741. 
Luecke, R. W., Hoefer, J. A., Brammel, W. S. \& Thorp, F. (1956). F. Anim. Sci. 15, 347.

Murthy, G. K., Goldin, A. S. \& Campbell, J. E. (1959). Science, r30, 255.

Mushett, C. W., Kelley, K. L., Boxer, G. E. \& Rickards, J. C. (r952). Proc. Soc. exp. Biol., N.Y., 81, 234 .

Najjar, V. A. \& Holt, L. E. (1943). F. Amer. med. Ass. 123, 683.

Nason, A. (1958). In Trace Elements Conference, Ohio Agricultural Experiment Station, Wooster, Ohio. [C. A. Lamb, O. G. Bentley and J. M. Beattie, editors.] London: Academic Press Inc.

Newland, H. W., Ullrey, D. E., Hoefer, J. A. \& Luecke, R. W. (r958). F. Anim. Sci. x7, 886.

Nicholas, D. J. D. (1957). F. Sci. Fd Agric. 8, Sr 5.

Nieweg, H. O., Shen, S. C. \& Castle, W. B. (1957), Proc. Soc. exp. Biol., N.Y., 94, 223.

Nishimura, H. (1953). $\%$. Nutr. 49, 79.

Owen, E. C. (1959a). Rev. Path. gén. 59, 224.

Owen, E. C. $($ r959b). Rev. Path. gén. 59, 23 I.

Owen, E. C. (1959c). Vet. Rec. 7x, I114.

Parizek, J. (1957). F. Endocrin. 15, 56.

Perpere, L. \& Placidi, L. (1956). Rec. Med. vet. 132, 913.

Pines, K. L. \& Crymble, M. M. (1952). Proc. Soc. exp. Biol., N.Y., 81, 160.

Plumlee, M. P., Thrasher, D. M., Beeson, W. M., Andrews, F. N. \& Parker, H. E. (1956). F. Anim. Sci. 15, 352.

Reisenauer, H. M. (1960). Nature, Lond., 186, 375 .

Sandell, E. B. (1944). Colorimetric Determination of Traces of Metals. New York: Interscience Publishers Inc.

Schwartz, M., Lous, P. \& Meulengracht, E. (1959). Ugeskr. Laeg. 121, 353.

Seekles, L. (1948a). Vet. F. 104, 203.

Seekles, L. (1948b). Vet. F. 104, 238.

Seekles, L. (1948c). Vet. $\mathcal{F}$. 104, 279 .

Smith, E. L. (1957). Chem. छ Ind. (Rev.) 76, 572.

Stevenson, J. W. \& Earle, I. P. (1956). F. Anim. Sci. 15, 1036.

Taylor, K. B., Mallett, B. J., Witts, L. J. \& Taylor, W. H. (1958). Brit. F. Haematol. 4, 63.

Taylor, K. B. \& Morton, J. A. (1959). F. Path. Bact. 77, I17.

Todd, D. (1959). F. clin. Path. 12, 238.

Underwood, E. J. (1956). Trace Elements in Human and Animal Nutrition. New York: Academic Press Inc.

Vallee, B. L. (1959). Physiol. Rev. 39, 443.

Vallee, B. L., Rupley, J. A., Coombes, T. L. \& Neurath, H. (1960). 7. biol. Chem. $235,64$.

Wacker, W. E. C. \& Vallee, B. L. (1959). Fed. Proc. 18, 345.

Wagle, S. R., Mehta, R. \& Johnson, B. C. (1958a). F. biol. Chem. 230, I37.

Wagle, S. R., Mehta, R. \& Johnson, B. C. (1958b). Biochim. biophys. Acta, 28, 215.

Wald, G. (1935). F. gen. Physiol. r9, 35 I.

Wilkie, W. J. \& Bussell, B. W. (1958). Aust. vet. F. 34, I 72.

Wintrobe, M. M. (1956). Clinical Hematology. 4th ed. London: Henry Kimpton.

Wokes, F. (1958). F. roy. Soc. Arts, 106, I 13.

Wokes, F. \& Piccard, C. W. (1955). Amer. F. clin. Nutr. 3, 383.

Wolff, R. \& Vuillemin-Weis, J. (r958). Bull. Soc. Chim. biol., Paris, 40, 1539.

\section{Comparative studies of copper, molybdenum and sulphur metabolism in the ruminant and the rat}

By C. F. MiLLs, Rowett Research Institute, Bucksburn, Aberdeen

It is now firmly established that high levels of molybdenum and sulphate in the diet of the sheep result in the depletion of tissue copper stores and the appearance of signs of copper deficiency. The mechanism of action of molybdenum and sulphate in producing these effects is unknown and has been the subject of much speculation (see, e.g., Dick, 1956).

Attempts have been made to study these interactions in non-ruminant animals such as the rat (Gray \& Daniel, I954; Van Reen, 1954; Miller, Price \& Engel, I956; 